\title{
ANALISIS KESULITAN SISWA SMA KELAS XI DALAM MEMPELAJARI UKURAN TENDENSI SENTRAL
}

\author{
AULIA AR RAKHMAN AWALUDIN \\ aulia_awaludin@yahoo.co.id \\ Universitas Indraprasta PGRI
}

\begin{abstract}
Abstrak. Penelitian ini bertujuan untuk mengetahui kesulitan belajar apa sajakah yang di alami siswa kelas XI SMA Batik 1 Surakarta pada materi statistika ukuran tendensi sentral data kelompok, apa penyebab kesulitan belajar siswa kelas XI SMA Batik 1 Surakarta pada materi statistika ukuran tendensi sentral data kelompok dan bagaimana alternatif pemecahan hasil analisis kesulitan belajar pada materi statistika ukuran tendensi sentral data kelompok. Metode yang digunakan berdasarkan studi kepustakaan. Hasil alternatif bagi siswa yang kesulitan pada pemahaman konsep adalah dengan menerapakan pembelajaran pendekatan kontekstual yaitu pembelajaran yang bertujuan memotivasi siswa untuk memahami makna materi yang di pelajarinya dengan mengkaitkan dengan konteks kehidupan sehari-hari seperti mengetahui rata-rata dari suatu nilai ulangan, mengetahui modus (nilai yang banyak didapat siswa) dari suatu ulangan sehingga pembelajaran akan membekas dan teringat oleh siswa dan bagi siswa yang kesulitan penerapan rumus dan penyelesaian adalah Alternatif yang diberikan adalah memperbanyak latihan soal dan perlu untuk penjabaran apa saja yang diketahui dan di dapat darimana. Ketika siswa sudah terbiasa dengan hal seperti itu maka siswa akan mudah dalam menerapkan rumus dan menyelesaikan soalnya dengan benar.
\end{abstract}

Kata kunci: analisis, tendensi sentral

\begin{abstract}
This study aims to determine the difficulties of learning what are the natural students of class XI SMA Batik 1 Surakarta on the material statistics the size of the central tendency of group data, what causes the difficulty of learning students class XI SMA Batik 1 Surakarta on the material statistics the size of the central tendency of group data and how the alternative Solving the results of the analysis of learning difficulties on the statistical matter of the size of the central tendency of group data. The method used is literature study. Alternative results for students who have difficulty in understanding the concept is to apply learning contextual approach is learning that aims to motivate students to understand the meaning of the material in the learning by associating with the context of everyday life such as knowing the average of a value of repetition, know mode (value Which many students get) from a repetition so that learning will be memoras and remembered by students and for students who have difficulty application of formulas and solutions is the alternative given is to multiply the exercise questions and need for the elaboration of what is known and can be from where. When students are accustomed to such things then students will be easy in applying the formula and solve the problem correctly.
\end{abstract}

Keywords: analysis, central tendency

\section{PENDAHULUAN}

Statistika merupakan pengetahuan yang berhubungan dengan cara-cara pengumpulan, penyusunan, pengolahan, penganalisisan, serta penyajian data berdasarkan kumpulan dan analisis data yang dilakukan (KTSP 2006). Adapun standar kompetensi yang ditargetkan dalam KTSP 2006 adalah menggunakan aturan statistika, kaidah 
pencacahan dan sifat-sifat peluang dalam pemecahkan masalah. Tujuannya agar peserta didik dapat memahami cara memperoleh data, menentukan jenis dan ukuran data, serta memeriksa, membulatkan, dan menyusun data untuk menyelesaikan masalah. Adapun kompetensi dasar yang harus dicapai diantaranya: Membaca data dalam bentuk tabel dan diagram batang, garis, lingkaran, dan ogive; Menyajikan data dalam bentuk tabel dan diagram batang, garis, lingkaran, dan ogive serta penafsirannya, dan Menghitung ukuran pemusatan, ukuran letak, dan ukuran penyebaran data, serta penafsirannnya.

Menurut Sukestiyarno dan Muslikah (2011) dalam penelitiannya mengenai permasalahan ukuran tendensi sentral data kelompok yaitu siswa masih bingung dalam membedakan jenis data tunggal, data bergolong sehingga siswa sulit dalam menerapkan dalam penyelesaian permasalahan soal dan peserta didik hanya disuruh menghafal suatu rumus yang sudah disajikan kepada peserta didik.

Materi statistika adalah salah satu materi matematika yang diajarkan pada semester 1 kelas XI. Materi ini adalah materi yang tentunya dikaitkan dengan materimateri sebelumnya. Terkadang pendidik hanya menyampaikan materi secara verbal tentang sifat-sifat, rumus statistika bulat. Peserta didik tanpa diberi kesempatan untuk mengetahui darimana hal itu diperoleh.

Berdasarkan data nilai ulangan harian materi statistika siswa kelas XI IPA 1 yang diperoleh dengan wawancara guru SMA Batik 1 Surakarta menunjukan bahwa masih ada sekitar 27 siswa dari 40 siswa yang masih belum memenuhi Kriteria Ketuntasan Minimum (KKM 77). Artinya siswa masih mengalami kesulitan belajar, adapun kesulitan belajar siswa tersebut pada materi statistika ukuran tendensi sentral antara lain kesulitan dalam pemahaman konsep, kesulitan dalam penerapan rumus dan penyelesaian soal. Kesulitan belajar tersebut ditemukan saat siswa mengerjakan soal sehingga berdampak pada kesalahan siswa dalam menyelesaikan soal.

Banyaknya kesalahan siswa dalam penyelesaian soal yang di akibatkan oleh kesulitan dalam pemahaman konsep dan kesulitan dalam penerapan rumus dan penyelesaian soal dapat menjadi petunjuk sejauh mana siswa dapat menguasai materi. Dari kesalahan yang dilakukan siswa akan diteliti penyebab kesulitan belajar siswa sehingga dapat ditemukan pemecahan masalah agar siswa tidak melakukan kesalahan yang sama.

Berdasarkan uraian di atas maka perlu dilakukan analisis mengenai kesulitan yang dialami siswa pada materi statistika ukuran tendensi sentral data kelompok dan alternatif pemecahannya. Diperoleh rumusan masalah sebagai berikut kesulitan belajar apa sajakah yang di alami siswa kelas XI SMA Batik 1 Surakarta pada materi statistika ukuran tendensi sentral data kelompok ? Apa penyebab kesulitan belajar siswa kelas XI SMA Batik 1 Surakarta pada materi statistika ukuran tendensi sentral data kelompok? Bagaimana alternatif pemecahan hasil analisis kesulitan belajar pada materi statistika ukuran tendensi sentral data kelompok?

\section{METODE}

Metode yang digunakan berdasarkan studi kepustakaan. Nazir (2003) mengemukakan bahwa studi kepustakaan adalah teknik pengumpulan data dengan mengadakan studi penelaahan terhadap buku-buku, literatur-literatur, catatan-catatan, dan laporan-laporan yang ada hubungannya dengan masalah yang dipecahkan.

\section{HASIL DAN PEMBAHASAN Instrumen}

Berikut adalah soal instrumen yang digunakan analisis tes tertulis pada makalah ini. 
1. Tentukan modus dari data di bawah ini

\begin{tabular}{|c|c|}
\hline Tinggi badan & Frekuensi \\
\hline $80-89$ & 2 \\
\hline $90-99$ & 6 \\
\hline $100-109$ & 10 \\
\hline $110-119$ & 14 \\
\hline $120-129$ & 9 \\
\hline $130-139$ & 7 \\
\hline $140-149$ & 2 \\
\hline
\end{tabular}

2. Tentukan Mean dari data di bawah ini

\begin{tabular}{|c|c|}
\hline Berat Badan & Frekuensi \\
\hline $60-69$ & 5 \\
\hline $70-79$ & 3 \\
\hline $80-89$ & 7 \\
\hline $90-99$ & 10 \\
\hline $100-109$ & 5 \\
\hline
\end{tabular}

3. Tentukan Median dari data di bawah ini

\begin{tabular}{|c|c|}
\hline Nilai & Frekuensi \\
\hline $60-64$ & 4 \\
\hline $65-69$ & 5 \\
\hline $70-74$ & 10 \\
\hline $75-79$ & 12 \\
\hline $80-84$ & 6 \\
\hline $85-89$ & 3 \\
\hline
\end{tabular}

\section{Penentuan Subjek}

Pengelompokan siswa di kelas XI IPA SMA BATIK 1 Surakarta yaitu dikelompokan dari kelas XI IPA $1-4$, artinya di SMA Batik 1 Surakarta ini telah dikelompokkan siswanya secara heterogen pada setiap kelas XI IPA 1 - 4. Setelah melakukan pertimbangan dan di sesuaikan dengan tujuan makalah, akan di pilih subjek siswa kelas XI IPA 1 yaitu Satria sebagai subjek 1 dan Jothat sebagai subjek 2.

\section{Analisis Jawaban Tertulis}

\section{Analisis kesulitan pada pemahaman konsep}

\section{Soal nomor 2}

Dari jawaban dalam gambar 1, subyek salah dalam menyelesaikan soal untuk menghitung data kelompok, subyek tidak menentukan nilai tengah pada tiap kelasnya, kemungkinan subyek berfikir banyaknya data pada interval itu terlihat pada tiap kelasnya sama dengan 10 semua, kemungkinan juga subyek masih berfikiran sama menghitung mean pada data tunggal. Kesulitan subyek dalam menentukan data yang digunakan menjadikan sebab kesalahan dalam penyelesaian soal. 


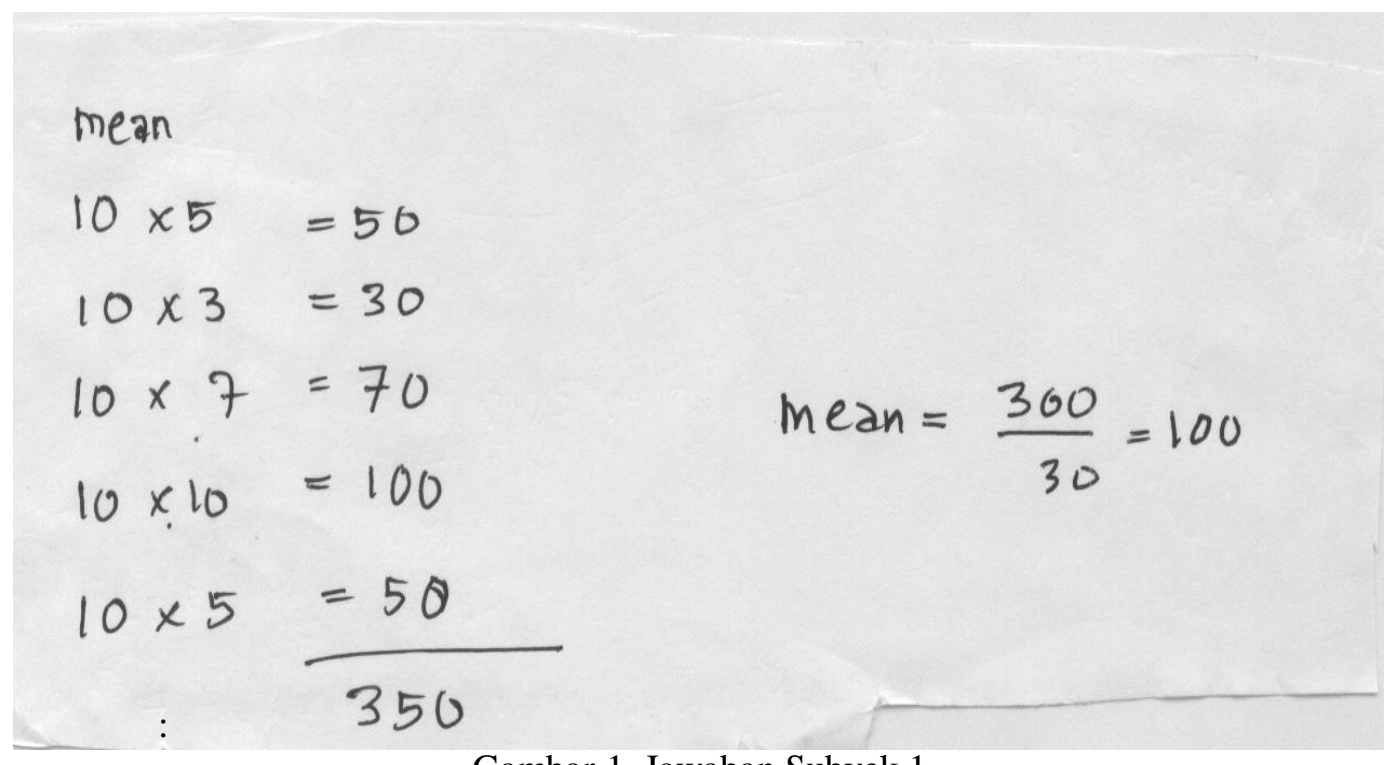

Gambar 1. Jawaban Subyek 1

$\begin{array}{lccl}\text { (7) Tinggi } & (f) & \text { nilaitangah }\left(x_{i}\right) & \text { fi.xi } \\ (60-69) & 5 & 64,5 & 322,5 \\ (70-79) & 3 & 74,5 & 223,5 \\ (80-89) & 7 & 84,5 & 591,5 \\ (90-99) & 10 & 94,5 & 949 \\ (100-109) & 5 & 104,5 & 522,5 \\ \sum(\text { gumlah }) & 30 & & 2605 \\ \bar{x}=\frac{\varepsilon\left(f i \cdot x_{i}\right)}{\varepsilon f}=\frac{2605}{30}=86,833 & \end{array}$

Gambar 2. Jawaban Subyek 2

Dari jawaban dalam gambar 2. dapat dilihat subyek sudah benar dalam menghitung mean data kelompok, subyek menentukan nilai tengah yang kemudian mencari jumlah total dari perkalian masing-masing nilai tengah dengan masing-masing frekuensi tiap kelasnya. Subyek sudah dapat menyelesaikan dengan baik, dirasa subyek tidak mengalami kesulitan dalam menentukan mean data kelompok.

\section{Analisis kesulitan pada penerapan rumus dan penyelesaian soal \\ Soal Nomor 1}

Dari jawaban subyek 1 dalam gambar 3. dalam menghitung modus data kelompok, kesulitan yaitu dalam penggunaan data untuk menghitung modus, subyek salah dalam menentukan d1 dan d2. Kemungkinan subyek tidak mengetahui cara menentukan $\mathrm{d} 1$ dan $\mathrm{d} 2$, sehingga kemungkinan subyek untuk menentukan $\mathrm{d} 1$ meggunakan frekuensi di atas frekuensi terbesar, dan menentukan d2 menggunakan frekuensi dibawah frekuensi terbesar. Kesulitan dalam penggunaan data sehingga mengakibatkan kesalahan dalam penyelesaian soal. 


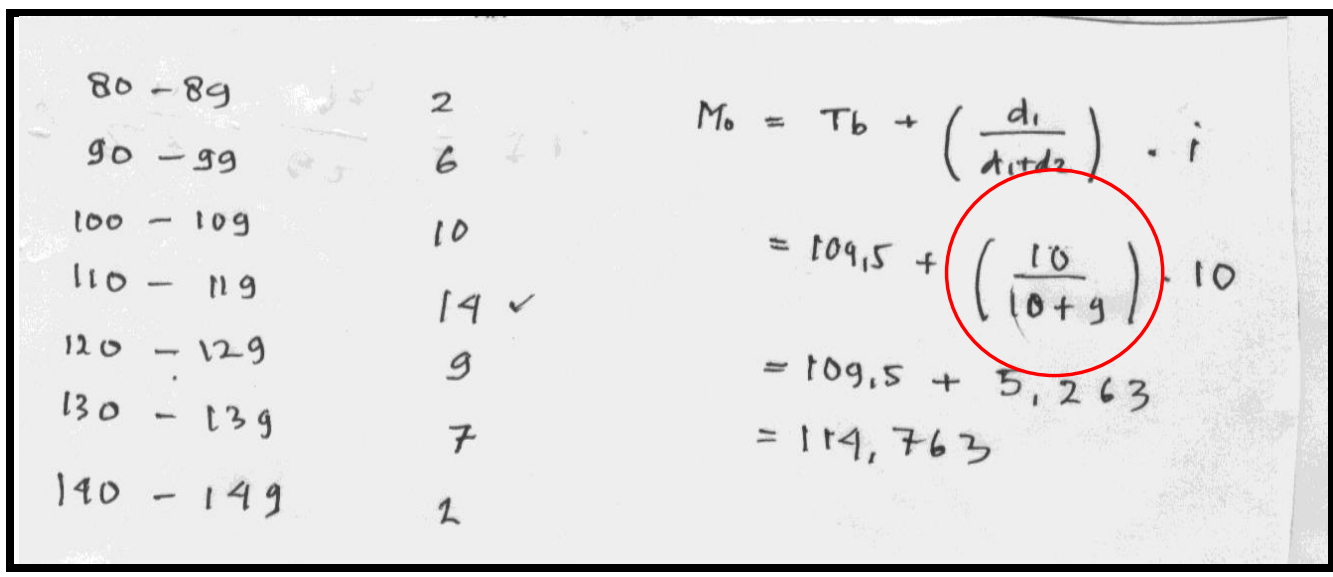

Gambar 3. Jawaban Subyek 1

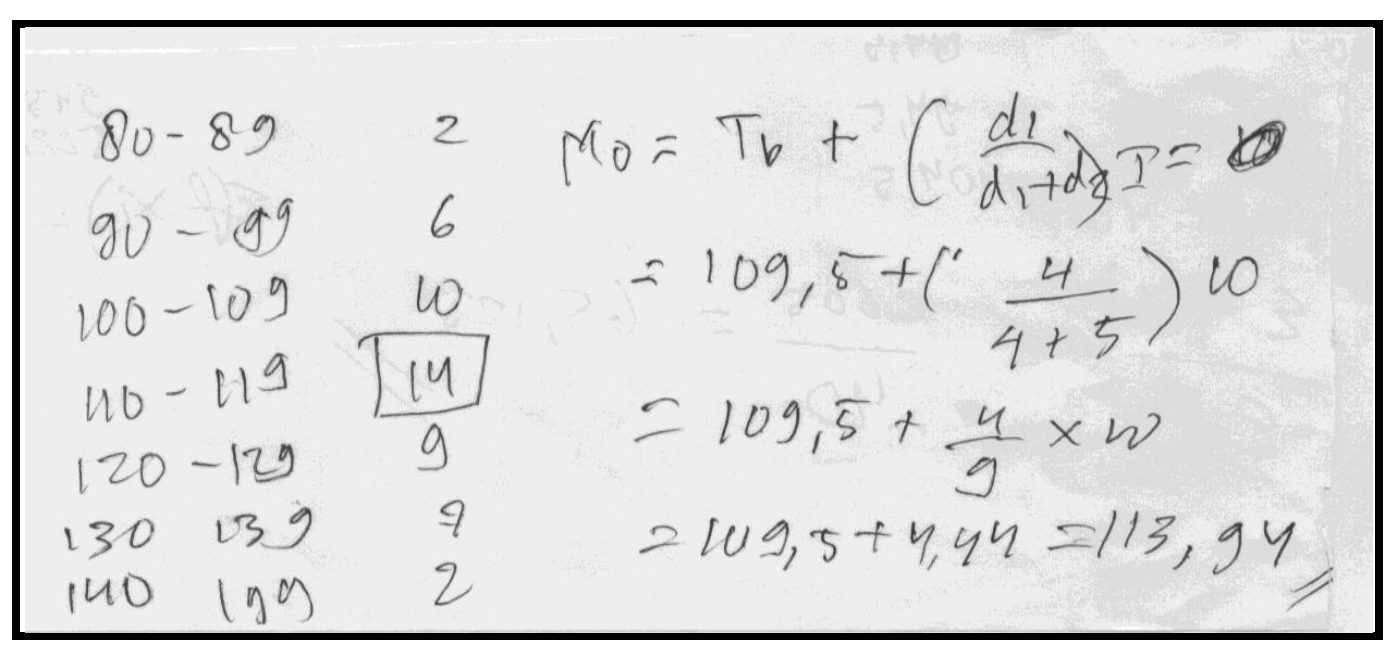

Gambar 4. Jawaban Subyek 2

Dari jawaban subyek 2 dalam gambar 4. dalam menghitung modus data kelompok subyek sudah bisa mengerjakan dengan baik. Subyek sudah dapat mengerti dalam penggunaan data yang digunakan dalam menghitung modus, hanya saja subyek tidak menuliskan apa yang diketahui dan didapat dari mana seperti mendapatkan d1 dan d2. Subyek tidak mengalami kesulitan dalam menghitung modus data kelompok karena dalam penggunaan data dan penyelesaian soal yang benar.

\section{Soal nomor 3}

Dari jawaban subyek 1 dalam gambar 5. subyek mengalami kesulitan dalam data yang digunakan kedalam rumus, terlihat saat menentukan nilai $\mathrm{F}$ kemungkinan subyek menggunakan F komulatifnya bukan jumlah frekuensi sebelum frekuensi kelas median. Kesalahan tersebut mengakibatkan kesalahan dalam penyelesaian soal.

Dari jawaban subyek 2 dalam gambar 6. sudah dapat mengerjakan dengan baik, subyek sudah dapat menentukan data yang digunakan untuk menghitung median data kelompok yang diterapkan kedalam rumus sehingga subyek dapat menyelesaikan soalnya dengan benar. Subyek tidak mengalami kesulitan dalam penerapan rumus dan penyelesaian soal. 


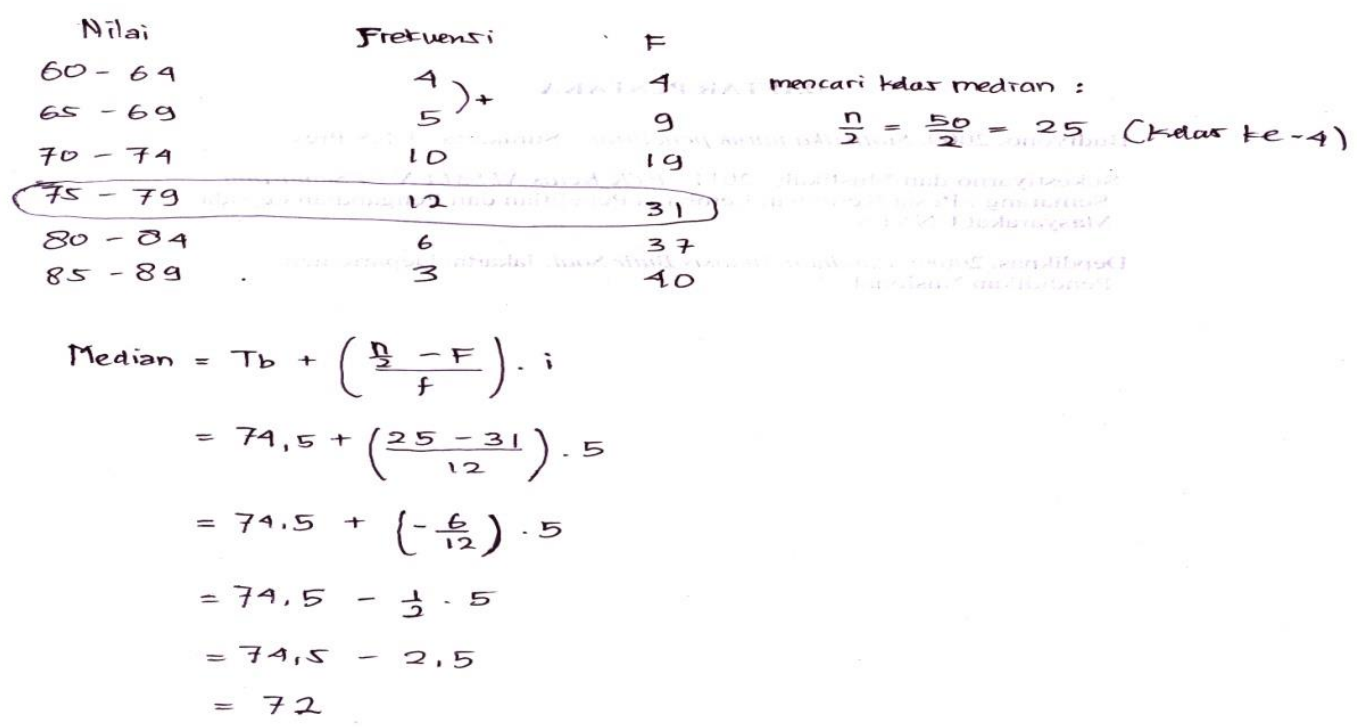

Gambar 5. Jawaban subyek 1

$$
\begin{aligned}
& \text { Milai } \\
& \text { Frekeasi } F \\
& \begin{array}{llll}
60 & -69 & 4 & 4
\end{array} \\
& 65-69 \quad 5 \quad 9 \\
& 70-74 \quad 10 \quad 19 \\
& 75-79 \quad 12 \quad 31 \\
& 80-84 \quad 6 \quad 37 \\
& 85-8930 \\
& \text { Medran }=T_{b}+\left(\frac{\frac{n}{2}-F}{f}\right) \cdot i \\
& =79,5+\left(\frac{25-19}{12}\right) 5 \\
& =79,5+\left(\frac{6}{12}\right) \cdot 5 \\
& =74,5+(0,5) \\
& =74,5+2,5 \\
& =77.0 \\
& \frac{n}{2}=\frac{50}{2}=25
\end{aligned}
$$

\section{1

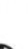

Gambar 6. Jawaban Subyek 2 


\section{Pembahasan Jawaban Tertulis dan Hasil Wawancara Kesulitan pada pemahaman konsep}

Kesulitan konsep adalah kesulitan siswa dalam menguasai konsep - konsep tertentu untuk menyelesaiakan suatu masalah.

Berdasarkan hasil analisis jawaban tertulis dan wawancara subyek 1 diperoleh kesulitan siswa dan penyebabnya adalah subyek tidak tepat dalam menentukan nilai tengah, subyek belum memahami konsep dari mean, sehingga subyek mengalami kesulitan dalam menyelesaikan soal.

Berdasarkan hasil analisis dan wawancara subyek 2 bahwa subyek 2 tidak mengalami kesulitan dalam menyelesaikan soal mean data kelompok ini, dan sudah memahami konsep sehingga subyek dapat menyelesaikannya dengan baik.

\section{Kesulitan pada penerapan rumus dan penyelesaian soal}

Kesulitan penerapan rumus adalah kesulitan siswa dalam menentukan data yang akan digunakan untuk menyelesaikan permasalahan.

Berdasarkan hasil analisis jawaban tertulis dan wawancara subyek 1 diperoleh kesulitan dalam menentukan data yang digunakan untuk menyelesaiakan soal, ketika subyek 2 salah dalam menentukan data yang digunakan akan berakibat kesalahan dalam menyelesaikan soal.

Berdasarkan hasil analisis jawaban tertulis dan wawancara subyek 2 bahwa subyek sudah dapat mengetahui data yang diperlukan untuk menyelesaikan soal, sehingga subyek 2 tidak mengalami kesulitan dalam hal ini.

\section{Alternatif Pemecahannya \\ Kesulitan pada pemahaman konsep}

Dari pembahasan yang dijelaskan bahwa penyebab kesulitan pemahaman konsep karena siswa masih mengacu kepada materi sebelumnya yaitu tendensi sentral data tunggal, sehingga siswa masih sering menggunakan rumus data tunggal yang menjadikan kesalahan siswa dalam memahami konsep. Oleh karena itu, alternatif pemecahan yang diberikan adalah dengan menerapakan pembelajaran pendekatan kontekstual yaitu pembelajaran yang bertujuan memotivasi siswa untuk memahami makna materi yang di pelajarinya dengan mengkaitkan dengan konteks kehidupan sehari- hari seperti mengetahui rata-rata dari suatu nilai ulangan, mengetahui modus (nilai yang banyak didapat siswa) dari suatu ulangan dan memberikan soal yang berkaitan dengan data tunggal dan kelompok sehingga siswa dapat membedakan saat mendapatkan permasalahan tersebut sehingga tidak melakukan lagi kesalahan seperti mulanya.

\section{Kesulitan pada penerapan rumus dan penyelesaian soal}

Dari pembahasan yang sudah dijelaskan bahwa penyebab kesulitan pada penerapan rumus adalah siswa salah dalam menentukan data yang akan digunakan untuk menyelesaiakan soal, sebaiknya siswa harus mengerti data mana saja yang digunakan dan darimana data tersebut di dapatkan, ketika kesulitan siswa dalam menentukan data yang diterapkan kedalam rumus maka akan berakibat juga kesalahan dalam penyelesaian soal. Alternatif yang diberikan adalah memperbanyak latihan soal dan perlu untuk penjabaran apa saja yang diketahui dan di dapat darimana. Ketika siswa sudah terbiasa dengan hal seperti itu maka siswa akan mudah dalam menerapkan kedalam rumus dan menyelesaikan soalnya dengan benar. 


\section{PENUTUP}

Berdasarkan analisis jawaban tertulis dan wawancara kelas XI IPA 1 SMA Batik 1 Surakarta dapat disimpulkan sebagai berikut

1. Penyebab kesulitan pada pemahaman konsep, kesulitan penerapan rumus dan penyelesaian soal

a) Siswa belum memahami materi yang telah di ajarkan gurunya, siswa kebanyakan masih lebih memahami ukuran tendensi sentral data tunggal daripada data kelompok, sehingga siswa berfikir akan sama dengan materi sebelumnya.

b) Siswa kurang mengerti darimana saja data yang diperlukan di dapat, dan karena kesalahan pada pengambilan data yang berakibat siswa salah dalam menggunakan data yang diterapkan kedalam rumus dan mengakibatkan penyelesaian soal yang salah.

2. Berdasarkan penyebab kesulitan siswa yang ditemukan maka alternatif pemecahan dari permasalahan tersebut yang dapat diberikan adalah sebagai berikut:

a) Alternatif bagi siswa yang kesulitan pada pemahaman konsep adalah dengan menerapakan pembelajaran pendekatan kontekstual yaitu pembelajaran yang bertujuan memotivasi siswa untuk memahami makna materi yang di pelajarinya dengan mengkaitkan dengan konteks kehidupan sehari-hari seperti mengetahui rata-rata dari suatu nilai ulangan, mengetahui modus (nilai yang banyak didapat siswa) dari suatu ulangan sehingga pembelajaran akan membekas dan teringat oleh siswa.

b) Alternatif bagi siswa yang kesulitan penerapan rumus dan penyelesaian adalah Alternatif yang diberikan adalah memperbanyak latihan soal dan perlu untuk penjabaran apa saja yang diketahui dan di dapat darimana. Ketika siswa sudah terbiasa dengan hal seperti itu maka siswa akan mudah dalam menerapkan rumus dan menyelesaikan soalnya dengan benar.

\section{DAFTAR PUSTAKA}

BSNP. 2006. Panduan Penyusunan Kurikulum Tingkat Satuan Pendidikan Jenjang Pendidikan Dasar dan Menengah. Jakarta: Badan Satuan Nasional Pendidikan.

Budiyono. 2009. Statistika Untuk Penelitian. Surakarta: UNS Press

Depdiknas. 2008. Panduan Analisis Butir Soal. Jakarta: Departemen Pendidikan Nasional.

Sukestiyarno \& Muslikah. 2011. Meningkatkan Hasil Belajar Matematika Materi

Statistika Kelas XI. Semarang: LPPM UNNES 